\title{
REFLEXÕES SOBRE A PROVA CIENTÍFICA NO PROCESSO CIVIL BRASILEIRO ${ }^{1}$
}

\section{REFLECTIONS ABOUT THE SCIENTIFIC PROOF IN BRAZILIAN CIVIL PROCESS}

Rafael Alves de Luna

Doutorando em Direito pela Universidade Católica de Pernambuco (Unicap). Membro da Associação Brasileira de Direito Processual (ABDPro). Pesquisador do Logos Processo, Linguagem e Tecnologia (Unicap). Possui graduação em Direito pela Universidade Católica de Pernambuco (2016) e mestrado em Direito pela Universidade Católica de Pernambuco (2018). Advogado. Recife/PE. Email: rafael_alves_luna@hotmail.com

José Mário Wanderley Gomes Neto Mestre em Direito Público e Doutor em Ciência Política pela UFPE. Professor na Universidade Católica de Pernambuco UNICAP e no Centro Universitário CESMAC. Recife/PE. Email: josemwgomes@gmail.com

Gabriela Suele Carneiro de Oliveira Pós-graduanda em Direito Civil e Processo Civil pela Escola Superior da Advocacia de Pernambuco (ESA-PE). Recife/PE. E-mail: gabi_suele@hotmail.com

\footnotetext{
${ }^{1}$ Artigo recebido em 08/05/2019 e aprovado em 29/08/2019.
} 
RESUMO: O presente escrito tem como objetivo debater a relação existente entre ciência e processo, notadamente no âmbito do direito probatório, tendo como fio condutor a utilização da prova científica. A fim de sanar essas inquietações, esta pesquisa se fundamenta metodologicamente em revisão de literatura especializada sobre o tema, caracterizando-a como uma pesquisa de natureza qualitativa. Tomando como pressuposto a ausência de regulação exauriente sobre o tema no CPC/15, logo em sua parte inicial, busca-se, por um viés histórico, a origem da aura de infalibilidade das conclusões científicas, elementar para o cenário atual da regulação. Logo em seguida, por ter discussões sobre o tema remontando os anos 20 do século passado, far-se-á uma breve incursão no cenário da prova científica no contexto estadounidense. Ao final, a partir das lições apreendidas anteriormente, expor-se-á tentativas de solução dos problemas atinentes à relação entre direito e ciência. Por fim, conclui-se que a inexistência de mecanismos de controle da prova científica no processo civil brasileiro permite a entrada de pseudociência/má ciência da cognição judicial, impactando no resultado final do processo.

PALAVRAS-CHAVE: Processo civil - direito probatório - epistemologia - prova científica

ABSTRACT: The purpose of this paper is to discuss the relationship between science and the process, especially in the field of evidentiary law, using the scientific evidence as the guiding principle. In order to remedy these concerns, this research is methodologically based on a review of specialized literature on the subject, characterizing it as a qualitative research. Taking for granted the absence of exaggerated regulation about this theme in $\mathrm{CPC} / 15$, in its initial part, through a historical bias, the origin of the infallibility of the scientific conclusions, elementary to the current scenario of regulation, is sought. Soon after, for having discussions about the theme going back to the 20's of the last century, there will be a brief incursion into the scene of scientific proof in the US context. In the end, from the lessons learned previously, attempts will be made to solve the problems related to the relationship between law and science. Finally, it is concluded that the lack of scientific evidence control mechanisms in the Brazilian civil process allows the entry of 
pseudoscience / bad science of judicial cognition, impacting the final outcome of the process.

KEY WORDS: Civil Procedure; Probative law; Epistemology; Scientific proof.

\section{Introdução}

Perante o atual contexto social, fundado sobre os pilares da ciência e tecnologia, não é de se espantar que a intersecção entre ciência e processo seja cada vez mais constante e íntima. Não é raro observar que a utilização de provas reputadas como científicas, ganham cada vez mais espaço, constituindo-se como elemento basilar das decisões judiciais.

Embora ganhe cada vez mais importância, essa relação entre ciência e processo carrega diversos problemas, que acabam surgindo com o fomento do debate. Uma primeira advertência que se deve fazer é que não se pode confundir prova científica (espécie) com prova pericial (gênero). Prova científica seria um resultado probatório, advinda da utilização de métodos científicos, caracterizado por uma metodologia regida por princípios próprios e de estrito rigor científico, que permite a falseabilidade - em termos Popperianos - no que tange a verificação empírica com possibilidade de repetição do experimento e, que por sua complexidade, sua análise e valoração escapam ao conhecimento e cultura média do magistrado ${ }^{2}$. Acresça-se a essa conceituação mais dois elementos, quais sejam, o grau de confiança no método na construção da prova e a assunção das conclusões científicas como conclusões probabilísticas.

Sobre os dois elementos acrescidos, no que toca o grau de confiança no princípio científico, é o elemento determinante na reputação de uma prova como científica ou não. É necessário que a conclusão advenha do seguinte caminho: pergunta - premissas - hipótese - resposta à hipótese através do método - resultado. Quanto mais reto o caminho percorrido, maior o grau de confiança no resultado, e em consequência no princípio

2 Conclusão semelhante chegou: SONEGHETI, Victor. $\mathbf{O}$ recurso à ciência no processo: a prova científica no direito processual civil brasileiro. 149 f. Dissertação (Mestrado) - Curso de Mestrado em Direito Processual Civil, Centro de Ciências Jurídicas e Econômicas, Universidade Federal do Espírito Santo, Vitória, 2012. p. 28. 
Revista Eletrônica de Direito Processual - REDP.

Rio de Janeiro. Ano 13. Volume 20. Número 3. Setembro a Dezembro de 2019

Periódico Quadrimestral da Pós-Graduação Stricto Sensu em Direito Processual da UERJ

Patrono: José Carlos Barbosa Moreira (in mem.). ISSN 1982-7636. pp. 409-429

www.redp.uerj.br

científico utilizado. Pode se afirmar que a prova científica deriva da concreta implementação do método cartesiano.

Sobre a prova científica como elemento probabilístico, há de ser considerado que no decorrer da história, as teorias científicas vão e vem, impulsionadas por novas dinâmicas informacionais, que trazem consigo uma elevação do intercâmbio de informações tecnológicas e científicas. Dessa forma, a teoria "A", considerada irrefutável, acaba por dar espaço à teoria "B", com uma velocidade nunca vista antes. Atualmente, a noção/aceitação da ideia de falibilidade das conclusões científicas é cada vez mais fortalecida pelo contexto a qual se insere a humanidade. No seio científico, já se internalizou a noção de que essa falibilidade não pode ser desconsiderada pelos cientistas. ${ }^{3}$

O grave problema que hoje se instaura em nossas cortes de Justiça, envolvendo o objeto de estudo, está no papel exercido pelo perito cientista para a resolução da lide. Não raras vezes, percebeu-se atuações jurisdicionais tendentes ao endeusamento das conclusões científicas, em paralelo a sua reputação como prova infalível. Surge a figura do magistrado ratificador de laudos. Dessa forma, revela-se uma clara tensão existente entre a função jurisdicional e o papel do cientista no deslinde da causa, levando em conta, a possibilidade de delegação da jurisdição ao cientista.

Tentando afastar parte dos problemas, a doutrina propõe pressupostos a serem observados pelo magistrado, no ato de admissibilidade da prova científica, justamente no intuito de quebrantar alguns desses preconceitos. Propõe-se, por exemplo, que deveria ser exigido do perito as seguintes informações: a) o percentual de erro encontrado nos testes realizados; b) se o método foi efetivamente testado pelos atuais especialistas; c) se o método é predominantemente aceito na área do conhecimento do qual advém; d) a coerência lógica da argumentação; e) verificação se o método científico foi aplicado nos fatos da causa e se tais fatos condizem com a população de referência ${ }^{4}$.

3 Um exemplo que pode ser dado envolve a prova científica mais utilizada: "O cálculo de probabilidade de paternidade (que na identificação criminal é a probabilidade de combinação) é o que gera o famoso resultado expresso geralmente em um número bastante próximo de 100, o "festejado" 99,9999\%. Para se chegar a esse resultado, é empregada uma técnica chamada análise bayesiana". ARRUDA, José Acácio. PARREIRA, Kleber Simônio. A prova judicial de ADN. Belo Horizonte: Del Rey. 2000. p. 57. Em resumo, as conclusões advindas de um exame de ADN advém de um cálculo probabilístico. Ressalte-se que isso se aplica fundamentalmente às ciências "duras".

4 ALMEIDA. Diogo Assumpção Rezende, A prova pericial no processo civil: o controle da ciência e a escolha do perito. Rio de Janeiro: Renovar. 2011.p. 135-136. 
Ante a presença dessas provocações doutrinárias, os pensamentos se direcionam a questionar: como as provas reputadas como científicas devem ser lidas e interpretadas pelo magistrado? Buscando respostas no Código de Processo Civil de 2015, viu-se que a proposta de admissibilidade - se é que há uma propriamente dita - mostra-se estanque e refratária de toda a influência científico-tecnológica no nosso contexto social, sendo inconcebível tal fato. A fronteira entre ciência e direito não se encontra demarcada, o que traz riscos tanto a uma quanto a outra.

Advertindo previamente o leitor, a interação entre direito e ciência não é nenhuma novidade. O Código de Processo Civil de 1939 continha um capítulo destinado ao tema dos "exames periciais". Entretanto, é inegável que a ciência/tecnologia é bem mais presente em nossas vidas e o acesso a ela é bem mais fácil do que no século passado, o que sem dúvida aumenta o nível de utilização dessa espécie probatória. Cumule-se a isso, uma maior aura de confiabilidade atribuída ao cientificismo, que chega aos pés da infalibilidade; fomentada pelo comportamento do julgador e pela legislação omissa em pontos nevrálgicos. Assim, o que era apenas um instrumento de auxílio ao magistrado, que tinha como condão o auxílio ao julgador da compreensão e desvendamento dos fatos, que recaiam em áreas do conhecimento que transbordavam a sua formação ${ }^{5}$, acabou por ser transformar em um carimbo de confiabilidade à decisão judicial.

O presente escrito tem como intenção debater essa relação entre ciência e processo, e o papel daquela no deslinde da causa, principalmente no cenário de ausência de regulação que se mostra no atual quadro legal. Inicialmente, é de se perquirir as origens da aura de infalibilidade das conclusões científicas. Em um segundo momento, faz-se um breve estudo da jurisprudência estadunidense sobre o tema, pois ali as discussões se encontram em um nível mais maduro, percebendo que lições podem ser aproveitadas pelo legislador nacional. Ao final, far-se-á uma análise do cenário da prova científica no Código de Processo Civil de 2015. O trabalho se pauta metodologicamente na forma de revisão de literatura, adentrando à categoria de uma pesquisa qualitativa, que consiste na análise da literatura especializada sobre o tema, seja ela nacional ou estrangeira, a fim de que se possa observar o estado atual da problemática proposta, com seus problemas e virtudes. 


\section{A elevação do racionalismo à instância supraparadigmática e suas repercussões no direito.}

Com o salto tecnológico na Idade Média/Moderna, fomentado principalmente pela ciência, dá-se um pontapé inicial a atribuição de ares de infalibilidade às conclusões científicas. Os pressupostos dessa virada paradigmática se resumem a quatro elementos, ou valores epistemológicos: a matemática, a simplicidade, a objetividade e a estabilidade.

A partir do século XI, a Europa sofreu uma série de transformações socioculturais, notadamente o aumento da produção agrícola e do contingente populacional urbano, o que trouxe uma mudança considerável aos cenários europeus. Nesse cenário, o crescimento econômico acelera, principalmente pelo aumento do intercâmbio entre as pessoas. Surge uma nova classe social, que traz consigo novos valores e atitudes. A burguesia faz sua fortuna através dos números. Com uma observação até descuidada, é possível se observar que os comerciantes e banqueiros eram antes de tudo calculadores do tempo, do espaço, dos riscos, sendo inegável que o seu sucesso estava atrelado intimamente à matemática ${ }^{6}$.

A matemática carrega consigo fatores que auxiliam diretamente a sua utilização, quais sejam a simplicidade e a validade universal de seus pressupostos. Assim, a matemática garantiu a segurança das relações econômicas, atribuindo-lhes certeza, validade e verificabilidade às transações comerciais.

Nesse ínterim, emerge na sociedade um humanismo mais forte, se sobrepondo, em boa parte, aos pensamentos da Igreja Católica da época, com esta já enfraquecida pelo movimento de "Reforma". Como a Igreja acabava por dominar todas as áreas sociais, um abalo em um de seus tentáculos acabou por ser o mote de "reformas" nas outras áreas, sobretudo nas ciências/filosofia. Além do enfraquecimento da fé nos dogmas religiosos católicos, houve também um enfraquecimento no sistema filosófico. "Deus centro do universo" é substituído por "homem centro do universo". A filosofia fundada na verdade 
Revista Eletrônica de Direito Processual - REDP.

Rio de Janeiro. Ano 13. Volume 20. Número 3. Setembro a Dezembro de 2019

Periódico Quadrimestral da Pós-Graduação Stricto Sensu em Direito Processual da UERJ

Patrono: José Carlos Barbosa Moreira (in mem.). ISSN 1982-7636. pp. 409-429

www.redp.uerj.br

revelada/razão subordinada a Deus passa por um bombardeio com o advento implacável da lógica-matemática. ${ }^{7}$

Nesse ambiente fomentado por grandes transformações, as mudanças de cunho paradigmático não tardariam a surgir no campo epistemológico: no que diz respeito às ciências em geral, a "medida de todas as coisas" passaria a ser o racionalismo matemático ${ }^{8}$. A assertiva ficava ainda mais verdadeira quando se observava que, no decorrer da Idade Média, surgiram inúmeros teoremas/teorias, supostamente de cunho científico, que já utilizavam a matemática como elemento de validade. Ressalte-se que até hoje alguns postulados daquelas eras ainda são utilizados, v.g., os experimentos de Newton e Galileu. Para os cientistas das referidas eras, a matemática, em caráter inquestionável, implacável e facilmente demonstrável, transforma-se em seu novo "Deus", capaz de oferecer ferramentas para resolver, ainda que formalmente, as grandes questões da humanidade.

Como segundo pressuposto, a objetividade estabelece a ideia de que é possível conhecer objetivamente o mundo. Assim, o cientista, no exercício de suas atividades, para descobrir e descrever os mecanismos de funcionamento de sua natureza deve guardar certa distância, a ponto de "ficar fora dela", tendo uma visão abrangente e privilegiada, discriminando o que é objetivo e o que é ilusório. Dessa forma, a observação será mais objetiva quanto mais se elimina o observador ${ }^{9}$.

Já a estabilidade diz respeito a uma pretensa não alteração da relação entre o sujeito e o objeto, como se aquele fato ou evento pudesse se replicar, sucessivas vezes, sem qualquer variação: nela, o mundo se apresentaria num estado de pronto e acabado ${ }^{10}$. Ao trabalhar com a concepção de que o mundo e um todo ordenado, cujas leis de

7 Uma mudança paradigmática que merece destaque com o advento do movimento Iluminista, é o movimento da descoberta. No âmbito medieval, havia a ideia de conhecimento revelado, através dos ensinamentos de Santo Agostinho (VASCONCELLOS, Maria José Esteves. Pensamento sistêmico: o novo paradigma da ciência. Campinas: Papirus, 2003. 2.ed. p. 58). No âmbito racional, tal revelação "desaparece" já que a natureza se apresenta ao homem, devendo o mesmo desvendar o funcionamento da mesma, como se a natureza fosse uma grande máquina.

8 Racionalismo pode ser descrito como a atitude de quem confia nos procedimentos da razão para a determinação de crenças ou de técnicas em determinado campo. ABBAGNANO, Nicola. Dicionário de filosofia. São Paulo: Marins Fontes., 2000. p. 821

9 VASCONCELlOS, Maria José Esteves. Pensamento sistêmico: o novo paradigma da ciência. Campinas: Papirus, 2003. 2.ed. p.89-90.

10 PEREIRA, Mateus Costa. O paradigma Racionalista e sua repercussão no direito processual brasileiro. 2009. 233 f. Dissertação (Mestrado) - Curso de Direito, Centro de Teologia e Ciências Humanas, Universidade Católica de Pernambuco, Recife, 2009. p.23. 
funcionamento, simples e imutáveis, podem ser conhecidas, o cientista procura conhecer as relações funcionais entre os dados e as respectivas variáveis ${ }^{11}$. Por fim, temos o ideal de simplicidade, que seria a crença de que diante da aparente complexidade do universo, há estruturas simples, que podem ser desvendadas pelo cientista, a partir de um arsenal de ferramentas metodológicas ${ }^{12}$.

Com o claro avanço da unidade epistêmica física-matemática, via utilização do racionalismo, o descurar do mundo através do pensamento lógico-matemático certamente ganharia adeptos em outros campos e terrenos do saber, transmutando-se numa espécie de elemento validador universal. Charlie Huenemann, afirma que os racionalistas, frequentemente, parecem pertencer a outro mundo, pois, o mundo que eles consideram verdadeiro não é mundo revelado pelos sentidos, e sim, um mundo descrito através de conceitos abstratos e da matemática ${ }^{13}$.

Com a influência do racionalismo em boa parte das áreas do conhecimento, ficando entranhado em boa parte das ideias que surgiam à época, o paradigma racionalismo acaba por se tornar um verdadeiro supraparadigma, que se relaciona a ideia de um paradigma de grande abrangência ${ }^{14}$. Ovídio Batista constatou que o racionalismo contaminou as mais diversas "escolas" do pensamento, onde as mesmas acabavam por se submeter aos mesmos princípios da lógica-matemática como elemento de validação ${ }^{15}$. Decerto que o direito, fruto cultural, não ficaria imune a essas influências, podendo se identificar dois grandes veios de influência, que podemos chamar de direta e indireta.

A direta é mais conhecida pelos juristas; é aquela que trouxe como consequência o movimento codicista-legalista, sendo aferível a partir da análise das codificações e pretensões à completude do sistema jurídico. Houve uma tentativa de "naturalização" do direito; procedimento com ligação umbilical ao paradigma racionalista. O homem pode conhecer a natureza através da razão, estudando-a como uma verdadeira máquina,

11 VASCONCELlos, Maria José Esteves. Pensamento sistêmico: o novo paradigma da ciência. Campinas: Papirus, 2003. 2.ed. p.80.

12 VASCONCELlOS, Maria José Esteves. Pensamento sistêmico: o novo paradigma da ciência. Campinas: Papirus, 2003. 2.ed. p.74.

13 HUENEMANN, Charlie. Racionalismo. Petrópolis: Vozes, 2012. p. 20.

14 BORGATTI NETO, Ricardo. Paradigma mecanicista: origem e fundamentos, São Paulo: Leopardo, 2012. p. 13.

15 SILVA, Ovídio A. Baptista da. Processo e ideologia: o paradigma racionalista. 2. ed. Rio de Janeiro: Forense, 2006. p. 73. 
Revista Eletrônica de Direito Processual - REDP.

Rio de Janeiro. Ano 13. Volume 20. Número 3. Setembro a Dezembro de 2019

Periódico Quadrimestral da Pós-Graduação Stricto Sensu em Direito Processual da UERJ

Patrono: José Carlos Barbosa Moreira (in mem.). ISSN 1982-7636. pp. 409-429

www.redp.uerj.br

desvendando assim as suas "engrenagens", que se constituíam como o verdadeiro conhecimento científico, então, o direito teve que se tornar "natural" para ser um objeto idôneo de ser o destinatário do pensamento racional. Em segundo momento, pós "naturalização", chegou o momento de "matematizá-lo" 16 - recorde-se que o movimento racional trabalha com as premissas advindas da lógica-matemática -, já que a razão funciona através dos números, o direito deve ser algo contável, medível e pesável, traduzindo à linguagem matemática.

Quanto à influência a indireta, essa é aquela cuja influência se dá no animus e no comportamento da figura do julgador, sendo de mais difícil aferição. Percebe-se que o contexto das problemáticas da prova científica se situa tanto num veio quanto no outro, mas, preponderantemente se situa no segundo, no veio indireto. A legislação somente valida, através de uma regulação frouxa um comportamento reprovável por parte do julgador, que acaba por atuar como um ratificador de laudos, que podem não ser tão científicos assim. Assim se descura os prejuízos advindos da influência indireta.

Volvendo ao contexto propriamente científico, a partir do século XX, o paradigma da ciência moderna começa a sofrer um verdadeiro bombardeio. O modelo moderno de se fazer ciência começa a sofrer diversas críticas. Como um dos expoentes desse movimento, temos Karl Popper ${ }^{17}$, que reconhece um caráter provisório do conhecimento científico e defendendo o falsificacionismo como critério de verdade para uma teoria científica ${ }^{18-19}$.

16 "A geometrização do direito quis transformá-lo em um sistema fechado e perene. A aspiração de dar perenidade ao direito fez com que o sistema tivesse na ordem, na neutralidade e na unidade, os seus conceitos basilares." GOMES NETO, José Mário Wanderley; NOGUEIRA, Felipe Santana Mariz. O paradigma racionalista e a rigidez das formas no Processo Civil. Revista de Processo. São Paulo. v. 33 . n. 160, p. 325-349, jun. 2008. p. 328.

17 "Contudo, só reconhecerei um sistema como empírico ou científico se ele for possível de comprovação pela experiência. Essas considerações sugerem que seja tomado como critério de demarcação não a verificabilidade, mas a falseabilidade de um sistema. [...] deve ser possível refutar, pela experiência, um sistema científico empírico." POPPER. Karl Raimund. A lógica da pesquisa científica. São Paulo:Cultrix. 2002. p. 42.

18 GERMANO. Marcelo Gomes. Uma nova ciência para um novo senso comum. Campina Grande:EDUEPB, 2011. 400p. p.149.

19 Trabalho interessante é o desenvolvido por David Goodstein que de maneira bastante didática consegue expor alguns mitos da ciências, ao confrontá-los com a realidade prática. Um dos mitos quebrantados por ele é o de que os cientistas possuem a mente aberta para o surgimento do novo, porém, o fato é que a ciência é um processo "adversarial", no qual cada ideia merece a defesa mais vigorosa possível, mesmo com prova em contrário. GOODSTEIN, David. How Science Works. Reference manual on scientific evidence. 2. ed. Washington, D.C.: Federal Judicial Center: Lexis Publishing, 2000. p. 78-79. 
Com esse manquitolar, os pressupostos epistemológicos da ciência moderna começam a ser acanhoados. A fim de exemplificação, no que diz respeito à objetividade de um observador emerso de toda a sua subjetividade e influência externa - Japiassu em sua obra $O$ mito da neutralidade científica, afirma que sendo a ciência um produto humano, a ciência também é afetada pelas vicissitudes sociais, sendo impossível a sua absoluta isenção de valorações de ideologias. Aliás, até o que é conceituado como científico é um problema, na medida em que essa definição não decorre de parâmetros ou critérios prévios e invariantes. Tais limites dependem de controles intersubjetivos, apresentados como resultado de uma "descentração" relativamente ao ponto de vista próprio, em direção ao sujeito epistêmico. ${ }^{20}$

Assim, o modelo de racionalidade que regeu boa parte da revolução operacionalizada na Idade Média, principalmente nas ciências duras, atualmente é anacrônico, merecendo ajustes. O que se propõe não é o total afastamento do método racionalista, e sim o ajuste de um modelo aos novos tempos. As proposições pós-modernas mais radicais não podem ser vistas como a salvação da humanidade, abraçando-se esse modelo por completo. Qualquer ser humano reconhece que o avançar científico é responsável por inúmeras conquistas da humanidade, mas o modelo "moderno" em sua forma original se mostra desgastado e totalitário, devendo ser revisto - e não extinto.

Neste sentido, a chuva de críticas que o racionalismo vem recebendo chega não para abolir, e sim para discutir questões como o mito da coerência lógica necessária do racional com o real, que sucumbe, perante as lacunas que surgem, bem como, o mito da universalidade que desmorona ao se deparar com questões para os quais o sistema não carrega respostas $^{21}$. Assim, não se pode pensar numa ideia de ciência produzida sem um método a ser seguido, bem como sem elementos controláveis e verificáveis, abolindo-se o sistema metodológico com um todo ${ }^{22}$.

JAPIASSU, Hilton. O mito da neutralidade científica. Rio de Janeiro: Imago Editora, 1975. p. 26teórica desta concepção como "movimento" de transformação das estruturas do processo civil brasileiro. 2003. 84 f. Dissertação (Mestrado) - Curso de Direito, Centro de Ciências Jurídicas, Universidade Federal de Pernambuco - UFPE, Recife, 2003. p. 25.

22 O que se mostraria perigoso, pois abriria espaço para pseudo-ciências, bem como ciências de baixa qualidade. 
Revista Eletrônica de Direito Processual - REDP.

Rio de Janeiro. Ano 13. Volume 20. Número 3. Setembro a Dezembro de 2019

Periódico Quadrimestral da Pós-Graduação Stricto Sensu em Direito Processual da UERJ

Patrono: José Carlos Barbosa Moreira (in mem.). ISSN 1982-7636. pp. 409-429

www.redp.uerj.br

A grande questão que se propõe é que as ciências duras acabaram por internalizar essas questões, mas, parece que tais discussões/internalizações ainda não chegaram aos ouvidos jurídicos, que ainda cultuam resultados científicos com olhos da Idade Média. Assim, causa estranheza que na oportunidade de ouro que ocorrera por ocasião da edição do Código de Processo Civil de 2015, não adveio qualquer mecanismo de admissibilidade de prova científica, confundindo-a à prova pericial. Parece que o direito brasileiro ainda se filia a noção de infalibilidade das conclusões científicas, o que merece censura e crítica. Antes das críticas propriamente ditas, é de se vislumbrar como estão as discussões nos EUA, onde os debates sobre o tema são travados desde 1923 (caso Frye), estando alguns passos à frente do que as discussões brasileiras.

\section{Da admissão/valoração da prova pericial: uma experiência estadunidense}

Readentrando o campo das conceituações, a prova pericial é aquela pela qual a elucidação do elemento fático se dá com o auxílio de um especialista em determinado campo do saber, devendo registrar sua opinião científica no chamado laudo pericial ${ }^{23}$. Diante do rol elencado no código de processo civil de 2015, tal método probatório se mostra bastante peculiar, pois a averiguação da prova é feita pelo perito, e não pelo magistrado ${ }^{24}$. Ressalte-se que o perito não pode prestar informações inverídicas, podendo ser responsabilizado por isso, mesmo a título culposo, devendo inclusive o juiz comunicar o fato ao respectivo órgão de classe ${ }^{25}$.

Humberto Theodoro Junior afirma que por se tratar de uma prova especial, com estrita subordinação a requisitos específicos, a perícia só pode ser admitida pelo juiz,

23 DIDIER JUNIOR, Fredie; BRAGA, Paula Sarno; OLIVEIRA, Rafael Alexandria de. Curso de Direito Processual Civil: teoria da prova, direito probatório, ações probatórias, decisão, precedente, coisa julgada e antecipação da tutela. 8. ed. Salvador: Juspodivm, 2013. 2 v. p. 231

24 Art. 156. O juiz será assistido por perito quando a prova do fato depender de conhecimento técnico ou científico.

25 Art. 158. O perito que, por dolo ou culpa, prestar informações inverídicas responderá pelos prejuízos que causar à parte e ficará inabilitado para atuar em outras perícias no prazo de 2 (dois) a 5 (cinco) anos, independentemente das demais sanções previstas em lei, devendo o juiz comunicar o fato ao respectivo órgão de classe para adoção das medidas que entender cabíveis. 
Revista Eletrônica de Direito Processual - REDP.

Rio de Janeiro. Ano 13. Volume 20. Número 3. Setembro a Dezembro de 2019

Periódico Quadrimestral da Pós-Graduação Stricto Sensu em Direito Processual da UERJ

Patrono: José Carlos Barbosa Moreira (in mem.). ISSN 1982-7636. pp. 409-429

www.redp.uerj.br

quando a apuração do fato controverso, não puder se concretizar pelos meios ordinários do convencimento ${ }^{26}$.

Diante de uma prova de tamanha importância, o Novo CPC limitou-se a apenas regular a parte procedimental da perícia, como por exemplo, a nomeação do perito, e os requisitos do laudo pericial, bem como a possibilidade de realização de uma segunda perícia, não dispondo nada sobre critérios de admissibilidade propriamente ditos da prova pericial.

Cenário diferente encontra-se nas cortes estadunidenses em que desde 1923 se discute tal matéria. Nesse ano o Circuit Court do distrito de Columbia se deparou com o caso "Frye vs United States", onde teve que decidir se aceitava ou excluía como prova um dos primeiros aparelhos de polígrafo num caso de homicídio. Neste caso fixou-se a tese não com força de precedente, mas, como um ponto de referência - de que um teste científico poderia ser admitido apenas quando fosse suficientemente estabelecido para ganhar a confiança de todos ou a chamada general acceptance. ${ }^{27}$

Esse caso acabou por estabelecer o critério da aceitação geral do conhecimento científico como primeiro critério para admissibilidade da prova científica. O caso Frye acabou por ser a régua para a admissibilidade da prova derivada de soro da verdade ${ }^{28}$,

26 THEODORO JÚNIOR, Humberto. Curso de Direito Processual Civil: Teoria geral do direito processual civil e processo de conhecimento. 52. Ed. Rev. Amp. Rio de Janeiro: Forense, 2011, v.1. p. 487.

27 "Just when a scientific principle or Discovery crosses the line between the experimental and demonstrable stages is difficult to define. Somewhere in this twilight zone the evidential force of the principle must be recognized, and, while the courts will go a long way in admitting expert testimony deduced from a well-recognized scientific principle or discovery, the thing from which the deduction is made must be sufficiently established to have gained the general acceptance in the particular field in which it belongs.” Frye v. United States, 293 F. 1013 (D.C. Cir. 1923). Disponível em: https://www.law.ufl.edu/_pdf/faculty/little/topic8.pdf. Acesso em 13 set 2017.

28 United States v. Solomon, 753 F. 2d 1522, 1526 ( $9^{\text {th }}$ Cir. 1985); No caso Ramona v. Superior Court, julgou-se o uso de Amytal de sódio numa criança molestada em que a corte se pronunciou nos seguintes termos: Unlike an analysis of the factors affecting eyewitness identification or the direct examination of a wound or injury, the use of sodium amytal to retrieve repressed memories of child sexual molestation is a scientific technique or method which is subject to the Kelly requirements of reliability and acceptance by the relevant scientific community. (People v. Jones, supra, 52 Cal.2d at p. 653; People v. Mendibles, supra, 199 Cal.App.3d at p. 1293; People v. Johnson, supra, 32 Cal.App.3d at p. 1001.) In this case, the patient was hospitalized, the drug was injected intravenously by a physician, and the patient was questioned by a licensed therapist. The procedure was given an aura of reliability not only by the locale and method of the interview, but by the therapist's assurances that only persons trained to lie under the drug's influence could do so. This procedure was, as a matter of law, a scientific technique, the reliability of which must be established by expert evidence to meet Kelly's requirements. 
Revista Eletrônica de Direito Processual - REDP.

Rio de Janeiro. Ano 13. Volume 20. Número 3. Setembro a Dezembro de 2019

Periódico Quadrimestral da Pós-Graduação Stricto Sensu em Direito Processual da UERJ

Patrono: José Carlos Barbosa Moreira (in mem.). ISSN 1982-7636. pp. 409-429

www.redp.uerj.br

hipnose, e exame toxicológico, dentre outros ${ }^{29}$. Com o passar dos anos, uma insatisfação por parte dos jurisdicionados com a quantidade de ciência de baixa qualidade que passou a ser admitida nos processos cresce, e acaba por pressionar as cortes americanas a abandonar o sistema de admissão pautado na "general acceptance", por se mostrar insuficiente.

No início da década de 90, a Suprema Corte Americana foi instada a se manifestar sobre a tese de que Federal Rules of Evidence ${ }^{30}$ teriam substituído o sistema de admissibilidade trazido pelo caso Frye. Tal provocação se deu no contexto do julgamento do caso "Daubert vs. Merel Dow Pharmaceuticals Inc" ${ }^{31}$. Tal caso que envolvia a analise do nexo entre o uso de um medicamento antináuseas por mulheres nos primeiros meses de gravidez e a má formação das crianças.

$\mathrm{Na}$ discussão, de um lado estava a indústria farmacêutica com trinta estudos publicados, nos quais demonstravam que o uso do medicamento Bendectin não ocasionava malformações nos bebês versus o polo autor que contava com o apoio de oito peritos que encontraram tal ligação através de estudos com animais. In caso, o depoimento dos peritos não foi aceito, pois a corte distrital não entendeu pela admissão do depoimento dos peritos, pois, seus experimentos não tinham sido submetidos a general acceptance ${ }^{32}$.

O caso chegou a Suprema Corte, onde ocorreu o afastamento da regra da aceitação geral como requisito para admissibilidade da prova pericial ${ }^{33}$. Porém, a corte não deixou tal questão longe de regulação. Neste mesmo caso fixou determinados requisitos a serem observados pelo magistrado no ato de aceitação e confiabilidade da prova científica. Tais requisitos são os seguintes: testabilidade - confundível com a controlabilidade/

29 Mesmo com sua baixa utilização - proporcionalmente ao tempo em que vigorou -, o critério da aceitação geral tornou-se regra geral nas cortes americanas a década de 90. MANZANO, Luís Fernando de Moraes. Prova pericial: admissibilidade e assunção da prova científica e técnica no processo brasileiro, São Paulo: Atlas, 2011. p. 190.

30 Disciplina a produção de provas no âmbito federal. Un altro fattore importante è rapresentato dall'entrata in vigore, nel 1975, dele Federal Rules of Evidence, che vengono poi prese a modelo dalla legislazione dela maggio parte degli Stati. Il dato più relevante, e per centi aspetti sorprendente, è che in esse non si fa alcun cenno del general acceptance test, e nei lavori preparatotori non si parla neppure dela decisione sul caso Frye. TARUFFO, Michele. Le prove scientifiche nella recente esperienza statuniense. Rivista trimestrale di diritto e procedura civile, ano L, n. 1, março de 1996. Itália: Milano, p. 234-235 31 Daubert v. Merrel Dow Pharmaceuticals, Inc., 509 U.S. 579 (1993). Disponível em: http://docs.justia.com/cases/supreme/509/579.pdf. Acesso em: 13 set 2017.

32 Daubert v. Merrel Dow Pharmaceuticals, Inc., 509 U.S. 579 (1993). Disponível em: http://docs.justia.com/cases/supreme/509/579.pdf. Acesso em: 13 set 2017.

33 Conclui-se que o critério da "aceitação geral" perdeu influência, não passando de princípio norteador da análise do juiz quando do exercício do juízo de admissibilidade da prova. 
falseabilidade da teoria ou técnica; percentual de erro notório ou potencial; a publicação da teoria e da técnica a fim de que a teoria seja fruto do controle por outros profissionais; consenso geral da comunidade cientifica relevante ${ }^{34}$.

Segundo Taruffo, tais critérios não se fizeram de forma exaustiva, mas, constitui-se um rol meramente exemplificativo de fatores que se destinam a guiar o magistrado na questão da admissibilidade ${ }^{35}$. Tanto o é que a doutrina cria novos critérios, como por exemplo, Sanders que trouxe o critério do "non-judicial uses", que requer que a teoria/técnica não tenham sidos desenvolvidas com fito exclusivo de sua utilização judicial $^{36}$.

Postumamente ao caso Daubert, houve o caso "General Electric vs. Joiner". O fato importante que se deu nesse caso foi a importante legitimação do juiz togado no exercício do juízo de admissibilidade da prova ${ }^{37}$. No caso o polo autor sustentou que a exposição a bifenilpoliclorinatos e seus derivados havia provocado o desenvolvimento de câncer de pulmão. O cerne da discussão seria os limites à discricionariedade do magistrado na tarefa de admitir a prova científica. Fixou-se a tese de que os requisitos trazidos pelo FRE 702, não é taxativo, podendo o magistrado, dentro de seu juízo de discricionariedade estabelecer outros requisitos, podendo refutar a prova científica ${ }^{38}$.

Em 1999, o Suprema Corte Americana foi novamente instada a se manifesta sobre a questão do controle judicial sobre a prova pericial. O caso Kumho Tire Co. vs. Carmichael. provocou a Corte a se pronunciar sobre a abrangência de aplicação dos critérios da admissão da chamada prova testemunhal técnica. No caso a parte autora promoveu uma ação de reparação de dano, decorrente de uma explosão de um pneu de uma minivan, causando um acidente automobilístico, ocasionando a morte de um passageiro, além de outros feridos. O perito contratado pelo polo autor afirmou que um defeito de fabricação

34 MANZANO, Luís Fernando de Moraes. Prova pericial: admissibilidade e assunção da prova científica e técnica no processo brasileiro, São Paulo: Atlas, 2011. p. 197.

35 TARUFFO, Michele. Le prove scientifiche nella recente esperienza statuniense. Rivista trimestrale di diritto e procedura civile, ano L, n. 1, março de 1996. Itália: Milano, p. 233-234.

36 SANDERS. Joseph. Kumho and how we know. Law and contemporary problems. North Carolina: Durham, v.64, nº 2-3, 2001. p. 389.

37 ALMEIDA. Diogo Assumpção Rezende, A prova pericial no processo civil: o controle da ciência e a escolha do perito. Rio de Janeiro: Renovar. 2011. p. 35.

38 MANZANO, Luís Fernando de Moraes. Prova pericial: admissibilidade e assunção da prova científica e técnica no processo brasileiro, São Paulo: Atlas, 2011. p. 208. 
havia causado a explosão, depois de inspeção do pneu. Contudo, verificou-se que a técnica utilizada pelo expert era reputada como não científica. ${ }^{39}$

Diante de tal contexto fático, a Suprema Corte decidiu que os requisitos estabelecidos no caso Daubert, se aplicam também aos depoimentos baseados em conhecimento técnico ou especializado, e não somente científico.

Até este ponto, observa-se que a discussão sobre admissibilidade da prova técnicacientífica nos EUA está bastante avançada. No Brasil, ainda não se estabeleceram critérios gerais/vinculantes no que diz respeito ao plano da admissibilidade. Vemos alguns lampejos/esperança de dias melhores, como recentemente tivemos no caso da fosfoetanolamina, em que o TJSP - no Agravo Regimental $n^{\circ}$ 2205847-43.2015.8.26.0000 - acabou por suspender as ações que determinavam o fornecimento do medicamento por sua natureza experimental, mas, nada mais concreto ou geral.

\section{Direito e ciência: reflexões sobre a falta de controle sobre o resultado da prova pericial}

Indubitavelmente, a importância do conhecimento científico e seu avanço são inegáveis, sobretudo no âmbito do processo, permitindo que o magistrado alcance o entendimento sobre determinados fatos, sobre os quais paira a controvérsia, possibilitando assim a resolução do conflito. É inegável que o avanço tecnológico e o próprio avançar científico cada vez mais exercem influência na resolução da lide, principalmente no que toca à admissão/valoração das provas científicas, representando assim mais uma possibilidade de comprovação dos fatos.

Analisando as disposições atinentes ao tema no Código de Processo Civil, identificase claramente um nó a ser desatado, qual seja, a supraconfiança das conclusões científicas. Ao revés do direito estadunidense, verifica-se que mesmo com o advento do $\mathrm{CPC} / 15$, o campo da admissibilidade da prova científica veio com poucas mudanças ${ }^{40}$. Uma dessas

39 Kumho Tire Co. v. Carmichael, 526 U.S. 137 (1999). Disponível em: https://www.law.cornell.edu/supremecourt/text/97-1709. Acesso em 17 dez 2017.

40 Neste contexto, utilizemos o termo admissibilidade na concepção de Eduardo Cambi: a admissibilidade é um requisito de legalidade constitucionalidade, já que, para o prova ser admitida deve respeitar as formas e o procedimento previsto na lei, bem como não estar em conflito com nenhum outro bem 
mudanças, que parece aos olhos desavisados ser a mais emblemática, em uma análise mais acurada, mostra-se com eficácia meramente formal ou de check-list. É o art. 473, do $\mathrm{CPC} / 15$.

No artigo retro, o legislador trouxe os elementos que devem constar no laudo pericial, mas, não determina de que forma devem ser valorados, ou impõe alguma cláusula de barreira ao cumprimento "insatisfatório" dos requisitos. Fala-se em insatisfatório em uma dimensão material, e não meramente formal. Como exemplo, se o método não for predominantemente aceito pelos especialistas da área, qual o destino do laudo pericial? Será que os magistrados e seus auxiliares atentarão para a "predominância de aceitação do método"? Com o Judiciário abalroado da forma que está tal analise, em tese, será feita de forma perfunctória, na base do "contém/não contém". Com isso, continua o problema da admissibilidade da prova científica.

Imbuídos de um pensamento de que a falibilidade da ciência é algo real, presente e de imprescindível apreciação, não se pode acatar a ideia de um magistrado omisso, que funcione como mero ratificador de laudo pericial, devendo sempre levar em consideração de que o laudo pericial, se produzido sob certas circunstâncias, é completamente inidôneo a comprovar qualquer coisa. Nem todo conhecimento apresentado como científico pode ser utilizado como prova ${ }^{41}$. O cerne da questão está em saber quais espécies de ciência podem ser consideradas idôneas a constituírem provas judiciais. Obviamente que tais questões adentrariam discussões de caráter filosófico-epistemológico sobre o critério da demarcação, por exemplo. No entanto, essas discussões não contam com um "lugar de fala" para juristas, por justamente falta a parte técnica a estes. Assim, não cabe o julgamento do que é ou não científico, mas, sim, saber de que forma o magistrado deve valorar a prova advinda das conclusões científicas, que se dará a partir da resposta do perito a determinados quesitos propostos e requisitos a serem atendidos.

Como primeiro item a ser valorado, inclusive previsto no art. 465 , do CPC/15, é o conhecimento no objeto do estudo por parte do perito. Obviamente, se o magistrado deseja obter uma conclusão científica acerca de motores, deverá nomear um especialista em

ou valor assegurado na Constituição ou nas leis que impeçam o ingresso da prova em juízo. CAMBI, Eduardo. A prova civil: admissibilidade e relevância. São Paulo: Revista dos Tribunais. 2006, p. 262.

41 TARUFFO, Michele. La prueba. Tradução de Laura Manríquez e Jordi Ferrer Beltrán. Madrid: Marcial Pons, 2008. p. 282. 
motores. Quanto a isso, não deve haver maiores problemas. O perito comprovaria sua expertises a partir da juntada de diplomas e certificados de cursos direcionados àquela área.

Como segundo requisito coloca-se a aceitação da teoria e do método adotado, no meio científico. Ressalte-se que o que se busca não é uma teoria/método irrefutável - já que conforme demonstrado, a ciência é um processo, estando em mudança o tempo todo e sim um a teoria/método que tenha consenso em uma determinada fatia dos especialistas, exemplo: qual o melhor objeto de análise para ADN? Cabelo, saliva, sangue... Pode haver doutrinadores que defendam que o melhor é o sangue, outros afirmarem que é cabelo, e assim sucessivamente. Portanto, deve o perito indicar o método utilizado e os motivos pelo qual o fizeram escolher esse método, através de linguagem simples e com coerência lógica, conforme os ditames do art. 473, III, e $\S 2^{\circ}$, do CPC/15. Ressalte-se que a fundamentação de escolha deva se dar por fundamentação dialética, apresentando a teoria "refutadora" e do porquê o perito acredita que ela não é aplicável ao caso.

Como terceiro requisito, elenca-se a possibilidade de verificação de que o método foi devidamente seguido $^{42}$ e que a cadeia de custódia de provas seguiu a lógica científica e legal, permitindo-se a rastreabilidade dos componentes da prova, e preservando a sua fiabilidade. Ressalte-se que essa discussão já é enfrentada no Processo Penal, principalmente com base no art. $245, \S 6^{\circ}$, do CPP, e discutida no STJ, no HC $\mathrm{n}^{\circ}$ 160622/RJ, sob a relatoria da Min. Assusete Magalhães ${ }^{43}$. Vale ressaltar, que sobre a prova mais utilizada na via judicial, o exame de DNA, há variadas matérias jornalísticas que informam que o Brasil carece de normas técnicas e fiscalização específica capazes de garantir a fiabilidade dos resultados do DNA. Dessa forma, é necessária a possibilidade, como garantia da ampla defesa e do contraditório, que o método seja capaz de ser revisto, bem como que seja possível a rastreabilidade do objeto de prova.

42 ALMEIDA. Diogo Assumpção Rezende, A prova pericial no processo civil: o controle da ciência e a escolha do perito. Rio de Janeiro: Renovar. 2011. p. 165.

43 "Sobre a importância da custódia da cadeia de provas: O rastreamento das fontes de prova será uma tarefa impossível se parcela dos elementos probatórios colhidos de forma encadeada vier a ser destruída. Sem esse rastreamento, a identificação do vínculo eventualmente existente entre uma prova aparentemente lícita e outra, anterior, ilícita, de que a primeira é derivada, dificilmente será revelado. Os suportes técnicos, pois, têm uma importância para o processo penal que transcende a simples condição de ferramentas de apoio à polícia para execução de ordens judiciais". PRADO, Geraldo. Prova penal e sistema de controle epistêmicos: a quebra da cadeia de custódia das provas obtidas por métodos ocultos. São Paulo: Marcial Pons, 2014, p.79. 
Revista Eletrônica de Direito Processual - REDP.

Rio de Janeiro. Ano 13. Volume 20. Número 3. Setembro a Dezembro de 2019

Periódico Quadrimestral da Pós-Graduação Stricto Sensu em Direito Processual da UERJ

Patrono: José Carlos Barbosa Moreira (in mem.). ISSN 1982-7636. pp. 409-429

www.redp.uerj.br

Como quarto requisito e último requisito proposto, como visto ao longo do presente trabalho, a ciência é um processo adversarial, tendo seus resultados apresentados em demonstrações probabilísticas. Assim sendo, deve constar no laudo pericial a taxa de erro do resultado, permitindo-se assim ao magistrado valorar a mais ou a menos determinada prova científica.

No que toca a assunção da prova científica como uma conclusão probabilística, no decorrer da história, as teorias vão e vem, impulsionadas sobretudo, pela nova dinâmica informacional, que traz consigo um maior intercâmbio de informações tecnológicas e científicas. Assim, uma teoria " $\mathrm{X}$ " considerada irrefutável, acaba por dar espaço à teoria "Y" com uma velocidade nunca antes vista. Atualmente a noção/aceitação da ideia de falibilidade das conclusões científicas é cada vez mais fortalecida pelo contexto a qual estamos inseridos. Há a aceitação também no próprio seio científico de que a falibilidade da ciência existe e não pode ser desconsiderada; sendo assim, as conclusões científicas antes endeusadas por apresentar um viés de certeza impossível de relativizar, aceita a colocação de uma margem de erro nas teorias formuladas e nos resultados advindos desta. As conclusões científicas são atualmente prova probabilísticas ${ }^{44}$.

Diante desse requisito, não se pode aceitar o laudo pericial, há a certeza absoluta no resultado obtido cientificamente, principalmente nos laudos que colocam como probabilidade de erro em $0 \%$. Como discutido, a ciência é mutável e instável, pondo-se em questão se a ciência seria a lente da visão do ponto arquimediano. Desta forma, não se pode dar $100 \%$ de certeza a um resultado baseado puramente em princípios científicos.

\section{Considerações finais}

Traçado um breve panorama crítico sobre a atual situação da prova científica no contexto do Código de Processo Civil brasileiro, algumas conclusões podem extraídas.

44 Um exemplo que pode ser dado envolve a prova científica mais utilizada: “O cálculo de probabilidade de paternidade (que na identificação criminal é a probabilidade de combinação) é o que gera o famoso resultado expresso geralmente em um número bastante próximo de 100, o "festejado" 99,9999\%. Para se chegar a esse resultado, é empregada uma técnica chamada análise bayesiana". ARRUDA, José Acácio. PARREIRA, Kleber Simônio. A prova judicial de ADN. Belo Horizonte: Del Rey. 2000. p. 57. Em resumo, as conclusões advindas de um exame de ADN advém de um cálculo probabilístico. Ressalte-se que isso se aplica fundamentalmente às ciências "duras". 
Decerto que a ciência em muito auxiliou a evolução a evolução da humanidade, mas não conseguiu evitar os questionamentos atinentes às suas formas de construção. A ciência perdeu o caráter de divindade, de irradiação quase religiosa, com dogmas inquestionáveis, para um caráter de questionabilidade de seus pressupostos. O resultado científico passa de certeza para uma probabilidade.

No entanto, ao se vislumbrar a legislação atinente à regulação da prova científica no Brasil, percebe-se que os juristas locais não apreenderam esse novo paradigma científico, tendo vista uma legislação insipiente e quase inexistente, o que acaba por trazer um quadro de inexistência de um sistema de admissibilidade da prova científica, capazes de afastar a má ciência/pseudociência do processo. Cabe o ressalte que o que se quer não é a atribuição de uma função epistêmica ao magistrado, mas sim, tomar maiores cuidados para que a resolução da lide não seja realizada com base em provas de baixa ou inexistente qualidade científica. Os magistrados precisam perceber que a sua função como judex est peritus peritorum não é afeita a mera ratificação de laudos periciais, devendo ter um papel mais atuante para obstaculizar tais problemas.

Mas a exigência não pode recair somente aos juízes. Cabe também ao legislativo no seu mister criar um sistema de admissibilidade para a prova científica a fim de ser instrumentalizado pelos atores processuais. Desta forma, diante da inércia, caminha-se cada vez mais para a admissibilidade de qualquer tipo de prova que tenha escrito "ciência" em seu cabeçalho, sem questionar se realmente aquilo é científico.

Assim a discussão não se mostra morta, tampouco irrelevante. Onde a ciência e a tecnologia ganham cada vez mais espaço, os indivíduos devem estar com os olhos abertos a fim de que se evite o retrocesso e o retorno ao endeusamento das conclusões científicas.

\section{REFERÊNCIAS}

ABBAGNANO, Nicola. Dicionário de filosofia. São Paulo: Marins Fontes, 2000.

ALMEIDA. Diogo Assumpção Rezende, A prova pericial no processo civil: o controle da ciência e a escolha do perito. Rio de Janeiro: Renovar. 2011 
Rio de Janeiro. Ano 13. Volume 20. Número 3. Setembro a Dezembro de 2019

Periódico Quadrimestral da Pós-Graduação Stricto Sensu em Direito Processual da UERJ

Patrono: José Carlos Barbosa Moreira (in mem.). ISSN 1982-7636. pp. 409-429 www.redp.uerj.br

.Da prova pericial. In: Fredie Didier Jr.; Lucas Buril de Macêdo; Ravi Peixoto; Alexandre Freire. (Org.). Coleção Novo CPC - Processo de Conhecimento - Provas. 1ed. Salvador: Editora JusPodivm, 2015, v. 3, p. 655-676.

BORGATTI NETO, Ricardo. Paradigma mecanicista: origem e fundamentos, São Paulo: Leopardo, 2012.

BOULOS JÚNIOR', Alfredo. História, sociedade \& cidadania: $2^{\circ}$ ano. São Paulo: Ftd, 2013.

CAMBI, Eduardo. A prova civil: admissibilidade e relevância. São Paulo: Revista dos Tribunais. 2006.

DIDIER JUNIOR, Fredie; BRAGA, Paula Sarno; OLIVEIRA, Rafael Alexandria de. Curso de Direito Processual Civil: teoria da prova, direito probatório, ações probatórias, decisão, precedente, coisa julgada e antecipação da tutela. 8. ed. Salvador: Juspodivm, 2013. 2 v.

GERMANO. Marcelo Gomes. Uma nova ciência para um novo senso comum. Campina Grande:EDUEPB, 2011. 400p.

GRECO, Leonardo. A prova no Processo Civil: do Código de 1973 até o novo Código Civil. Revista Dialética de Direito Processual, São Paulo, v. 15, p. 76-94, 2004.

GOMES NETO, José Mário Wanderley. O acesso à justiça em Mauro Cappelletti: Análise teórica desta concepção como "movimento" de transformação das estruturas do processo civil brasileiro. 2003. 84 f. Dissertação (Mestrado) - Curso de Direito, Centro de Ciências Jurídicas, Universidade Federal de Pernambuco - UFPE, Recife, 2003. p. 25.

; NOGUEIRA, Felipe Santana Mariz. O paradigma racionalista e a rigidez das formas no Processo Civil. Revista de Processo. São Paulo. v. 33. n. 160, p. 325-349, jun. 2008. p. 328.

GOODSTEIN, David. How Science Works. Reference manual on scientific evidence. 2. ed. Washington, D.C.: Federal Judicial Center: Lexis Publishing, 2000.

HUENEMANN, Charlie. Racionalismo. Petrópolis: Vozes, 2012.

JAPIASSU, Hilton. O mito da neutralidade científica. Rio de Janeiro: Imago Editora, 1975. 
KUHN, Thomas. A Estrutura das Revoluções Científicas. 11.ed.São Paulo: Perspectiva, 2011.

MANZANO, Luís Fernando de Moraes. Prova pericial: admissibilidade e assunção da prova científica e técnica no processo brasileiro, São Paulo: Atlas, 2011.

PEREIRA, Mateus Costa. O paradigma Racionalista e sua repercussão no direito processual brasileiro. 2009. 233 f. Dissertação (Mestrado) - Curso de Direito, Centro de Teologia e Ciências Humanas, Universidade Católica de Pernambuco, Recife, 2009.

POPPER. Karl Raimund. A lógica da pesquisa científica. São Paulo:Cultrix. 2002.

SANDERS. Joseph. Kumho and how we know. Law and contemporary problems. North Carolina: Durham, v.64, nº 2-3, 2001.

SILVA, Ovídio A. Baptista da. Processo e ideologia: o paradigma racionalista. 2. ed. Rio de Janeiro: Forense, 2006.

SONEGHETI, Victor. $\mathbf{O}$ recurso à ciência no processo: a prova científica no direito processual civil brasileiro. 2012. 149 f. Dissertação (Mestrado) - Curso de Mestrado em Direito Processual Civil, Centro de Ciências Jurídicas e Econômicas, Universidade Federal do Espírito Santo, Vitória, 2012.

TARUFFO, Michele. La prueba. Tradução de Laura Manríquez e Jordi Ferrer Beltrán. Madrid: Marcial Pons, 2008.

TARUFFO, Michele. Le prove scientifiche nella recente esperienza statuniense. Rivista trimestrale di diritto e procedura civile, ano L, n. 1, março de 1996. Itália: Milano. THEODORO JÚNIOR, Humberto. Curso de Direito Processual Civil: Teoria geral do direito processual civil e processo de conhecimento. 52. Ed. Rev. Amp. Rio de Janeiro: Forense, 2011, v.1.

VASCONCELlOS, Maria José Esteves. Pensamento sistêmico: o novo paradigma da ciência. 2. ed. Campinas: Papirus, 2003. 